Pobrane z czasopisma Annales H - Oeconomia http://oeconomia.annales.umcs.pl Data: 26/04/2023 16:55:39

DOI:10.17951/h.2015.59.3.125

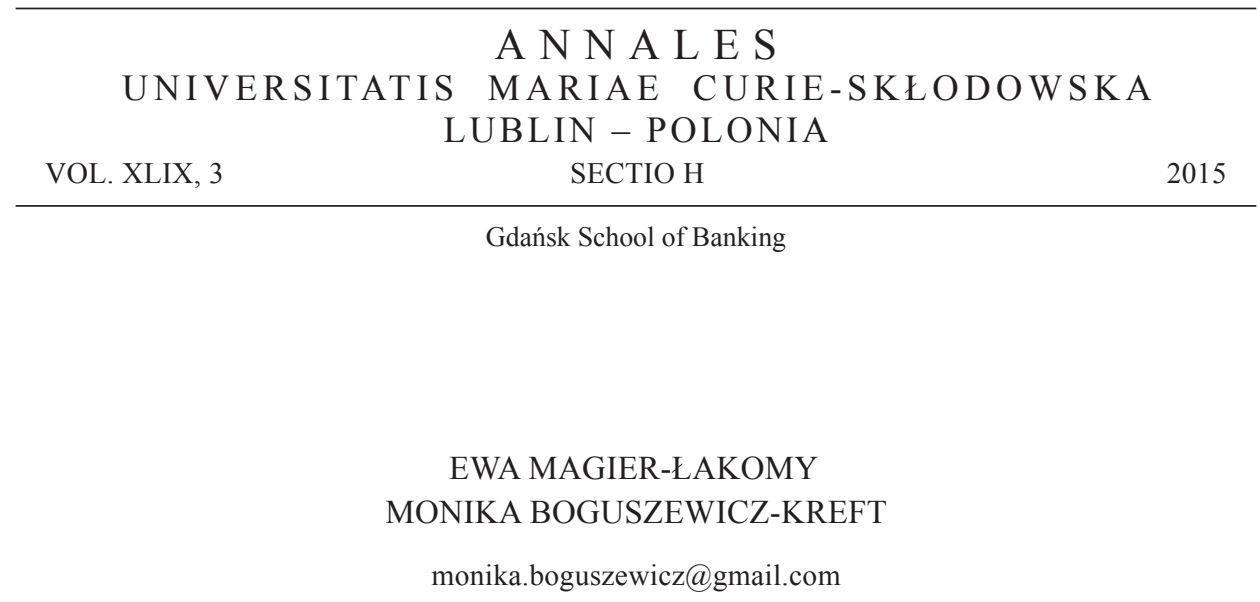

\title{
Dimensions of the Country of Origin Effect and their Measurement
}

Wymiary efektu kraju pochodzenia i ich pomiar

Keywords: country-of-origin (COO) effect, country of origin image, $\mathrm{COO}$ effect's dimensions, attitude, Polish consumers, consumers' behaviour.

Słowa kluczowe: efekt kraju pochodzenia, wizerunek kraju pochodzenia, wymiary efektu kraju pochodzenia, postawa, polscy konsumenci, zachowania konsumenckie.

JEL Code: M31, L8

\section{Introduction}

The dynamic growth of trade exchange and globalisation processes result in the fact that most consumer decisions are connected with purchasing goods coming from other countries. These countries' images influence consumer attitudes concerning their perception, opinions and purchasing behavior. This phenomenon has been defined as the country of origin effect (COO effect). Considering such a context, an important research challenge is to measure this influence (the COO effect itself) and particular components of the $\mathrm{COO}$ effect.

Research identifies three approaches to the general problem of the country of origin (Roth, Diamantopoulos, 2009): 1/ concentrating on the general image of the country, $2 /$ considering both the image of the country and the image of products which come from this country, $3 /$ focusing on the image of products coming from 
particular countries. The following analysis takes the third approach and it aims at the verification of a hypothesis concerning multiplicity of dimensions which co-create the image of products and services coming from various countries.

So far, studies which were carried out, did not give a clear answer, whether $\mathrm{COO}$ effect is multi- or uni-dimensional.

Therefore, the particular research questions have been formulated as follows:

1. Is the $\mathrm{COO}$ effect multidimensional?

2. What is the rate of variance of the $\mathrm{COO}$ effect dimensions and what is its importance?

The data have been collected with the use of the survey questionnaire. To process the obtained data statistically, the analysis of variance and one sample $t$-test have been applied.

\section{The concept of a consumer attitude in the $\mathrm{COO}$}

The consumer attitude comes as a result of cognitive processes (for example: consumers' belief in the industrial development and advanced technology in a particular country, which are associated with the quality and characteristics of products offered by this country), of affective processes (emotional and symbolic values which are attributed to the country of origin), of conative processes (the level of interaction with a particular country desired by consumers) ${ }^{1}$, and of normative processes (the impact of social standards, e.g. inspired and given media publicity boycott actions taken by consumers to retaliate against particular political decisions) (Balabanis and Diamantopoulos, 2011; Bloemer, Brijs and Kasper 2009). However, as some psychological research suggests (Wojciszke, 2011), the multifactorial concept of the attitude can well characterize attitudes towards particular objects. In the case of objects which have more abstract or symbolic character, the distinguished elements of the attitude merge together, and they become more difficult to identify. Therefore, it can be assumed that in the case of products seen as material objects, the attitude measurement based on its tri-factorial concept may be effective, whereas in the case of services with intangibility as their key dimension, it seems reasonable to provide a global research on the attitudes towards them.

In the following publication, a general definition of an attitude has been accepted as "an evaluative attitude based on cognitive elements, emotional reactions and intentions towards the future, and on behaviour" (Leippe and Zimbardo, 2004, p. 52). Hence, an attitude is to be understood as global orientation. The empirical indicator of this orientation is assumed to be a declarative evaluation of services and products.

1 Coming as three components of attitudes which are reflected in the structure of the country image (Laroche et al., 2005). 


\section{The country of origin (COO) and its influence on consumers}

Schooler (1965) started the research on the influence that an image of the country of origin has on processes concerning evaluation of products and on purchasing behaviour (COO effect, for relevant literature reviews, see e.g.: Bikely and Nes, 1982, Al-Sulaiti and Baker, 1998; Peterson and Jolibert, 1995; Javalgi, Cutler and Winans, 2001; Pharr, 2005; Rezvani et al., 2012; Saran and Gupta, 2012). Since then, this phenomenon has become one of the most often analysed in scientific research in the field of international marketing and consumer behaviour.

This phenomenon refers to the influence of a particular country image on evaluation of products and brands from that country (Liczmańska, 2010). Despite the fact that consumers' identification of the COO most often has an unintentional subjective character, and is not always accurate (Balabanis and Diamantopoulos, 2008; Zhou, Yang and Hui, 2010), (Balabanis and Diamantopoulos, 2011; Melnyk, Klein and Völckner, 2012), it has been also discovered that it results in assuming certain attitudes and consumer behaviour (Sikora, 2008; Balabanis and Diamantopoulos, 2011; Parr, 2005).

\section{The measurement of the COO influence on consumers' opinions about products and services}

$\mathrm{COO}$ was primarily perceived as a one-dimensional category (e.g. Hong and Wyer, 1989). However, after over twenty years of research, it started to be considered a complex category (Dinnie 2004, cit. in: Meng 2007). In the 1980s numerous concepts of various components of this phenomenon appeared (e.g. Johansson, Douglas and Nonaka, 1985). Their importance and impact started to be analysed in connection to the image perception of the country of product origin. The scientists were interested not only in the fact that the $\mathrm{COO}$ effect exists, but also in searching for answers to the question: why the differences in evaluation and in preference of products from various countries appear.

After the analysis of attributes used in other surveys of consumers' opinions on products in the context of the COO, Roth and Romeo (1992) presented a model composed of four dimensions:

1. Innovativeness - use of new technology and advanced engineering.

2. Design - appearance, style, colors, variety.

3. Prestige - exclusivity, status, brand name reputation.

4. Workmanship - reliability, durability, craftsmanship, manufacturing quality.

This study verifies the given model after its previous modification. The changes result from the efforts to adapt this model to the analysis of not only material goods (as it was primarily meant for this purpose), but also to the analysis of services. The modified model was previously used by Bose and Ponnam (2011). They focused their research on the evaluation of entertainment services (music, dance, circuses, 
theatres, films) by young citizens of India. The authors stated that some criteria of the evaluation which were used in Roth and Romeo's model, and which pertain to material goods, were not adequate while discussing the analysed services. Therefore, they assumed the following dimensions: innovativeness, diversity, exclusivity, and quality.

Adjusting the above criteria to the requirements of the $\mathrm{COO}$ analysis concerning services in general, the presented study assumes the following dimensions of the country image:

1. Innovativeness - understood as the use of the latest knowledge and advanced technology,

2. Diversity - namely: variety, wide range, and attractiveness of an offer,

3. Prestige - defined by exclusivity, status, brand name reputation,

4. Quality - seen as efficiency, durability, professionalism.

\section{The research method}

Participants. The data were collected from 129 Polish students ${ }^{2}$ of economic study courses: 55 men (43\%), 73 women $(57 \%)$. The mean participant's age was $\mathrm{M}=23.9 ; S D=6.77$. Participation in the study was voluntary and anonymous.

Questionnaire. The research was based on a questionnaire elaborated by the authors and consisted of several questions. Due to the aim of the study only the data from four questions were introduced to further analysis. The questions concerned the participants' attitude to products and services offered in 9 European countries ${ }^{3}$. The respondents completed their questionnaire forms using a six-grade scale.

Country selection. 5 countries were selected for further analysis. Poland as the country of respondents' residence and as the localization reference for the remaining four countries. The main criteria for choosing them was geographical in character: Germany - as a western country, Lithuania - as an eastern country, Hungary - as a southern country, Sweden - a northern country, referring to Poland.

2 Participants were recruited from a student's sample due to the lack of differences in COO between students and regular consumers (results were obtained in previous studies, i.e. Verlegh, Steenkamp (1999).

3 Questions were as follows: $1 \backslash$ How would you rate innovativeness (understood as the use of the latest knowledge and technology) of products and services according to the country of origin on a scale of $1-6$ (1 - very low, 6 - very high)?; $2 \backslash$ How would you rate diversity (understood as the appearance, style, the range of the offer of products and services according to the country of origin on a scale of $1-6$ ?; $3 \backslash$ How would you rate quality of the products and services understood as reliability, durability, professionalism on a scale of $1-6 ? ; 4 \backslash$ How would you rate prestige (understood as exclusivity, status, reputation) of products and services according to the country of origin on a scale of $1-6$ ? 


\section{Results}

In order to test the assumption that the $\mathrm{COO}$ effect is a multidimensional, an analysis of variance with repeated measures was conducted. Two independent variables were introduced to the analysis: COO dimension (4: innovativeness, diversity, quality, prestige), and country (5: Germany, Hungary, Lithuania, Poland, Sweden). All analyses were conducted with STATISTICA 10 software.

The main effect of the country (independently of dimension factor; $F(4,504)=$ 255,67. 65; $\left.p<0.0001, \eta^{2}=0.67\right)$ showed that there is a difference in products and services evaluation between given European countries. These results confirm the COO effect but it is rather replicating in character and it was not the main aim of the study.

The analysis also revealed a significant main effect for the dimension variable (independently of the country factor; $F(3,378)=2.94 ; p<0.05, \eta^{2}=0.02$. The detailed analysis showed that European products and services are evaluated at the highest level with regard to their quality $\left(M_{Q}=3.920\right.$, which is significantly higher comparing to diversity $\left(M_{D}=3.80 ; L S D: \mathrm{p}<0.05\right)$, prestige $\left(M_{P}=3.80, L S D: \mathrm{p}<0.01\right)$, and innovativeness $\left(M_{I}=3.82, L S D: p<0.05\right)$. The difference between quality and innovativeness $\left(M_{I}=3.82\right)$ was not significant $(L S D: \mathrm{p}>0.05)$. Obtained results show that European products and services are not evaluated equally to the extent of all given dimensions. That can be taken as a preliminary and indirect confirmation that introducing different dimensions to the study was relevant.

A significant interaction of two variables (country $x$ dimension) was found, $F(12$, $1512)=8.58, p<0.0001, \eta^{2}=0.06$ see Figure 1$)$.

All dimensions were evaluated at the highest level for Germany. Innovativeness, diversity, quality, and prestige for German products and services were evaluated significantly higher comparing to all remaining countries (most of $L S D$ tests: $p<0.00001$ ). In comparison with four remaining countries, products and services originated in Lithuania were evaluated most negatively, no matter what kind of dimension was a subject of respondents' consideration. That gives a shallow impression that regardless of the criteria, German products are good and Lithuanian are bad. However, significant differences between dimensions for a given country were observed.

In addition, another analysis (single sample $t$-test) was conducted to check whether the evaluation of products and services in terms of a given criteria differs from a neutral attitude at a significant level (see Table 1).

Germany. Diversity was evaluated significantly lower comparing to innovativeness $(L S D: p<0.001)$, to quality $(L S D: p<0.0001)$ and to prestige $(L S D: p<0.0001)^{4}$. There was no significant difference between remaining criteria: innovativeness, quality, prestige ( $L S D: p>0.05$ ). That means that German products are highly appreciated for these criteria and less for their diversity. All the obtained outcomes concerning services and products from Germany have been evaluated significantly above the

\footnotetext{
4 All compared means are presented in Table 1.
} 


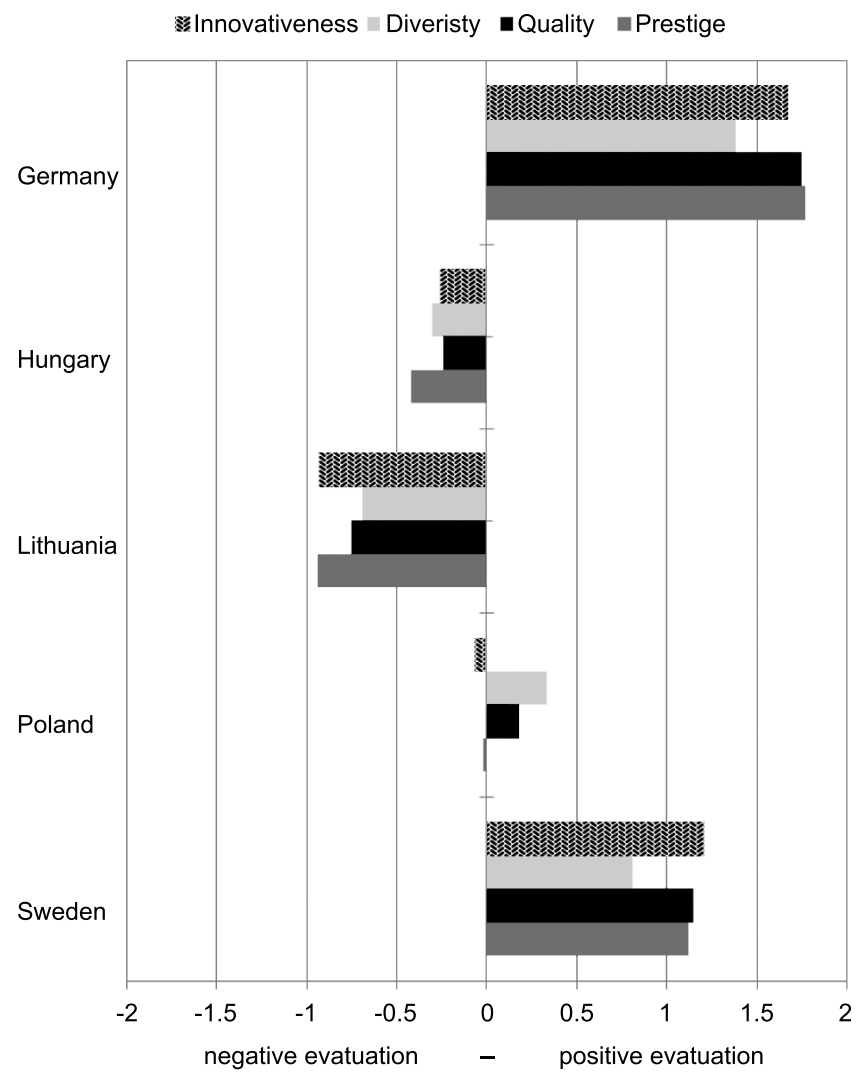

Figure 1. Evaluation of products and services according to the country of origin and model's criteria.

The scale of the questionnaire was 1(low) to 6(high). As a neutral reference point 3.5 has been taken (and presented as 0 at the plot). The outcomes presented at the plot were calculated as the difference between the obtained mean and the neutral reference point (i.e.: $M$ - 3.5). For example the mean for innovativeness of Polish products and service was $M_{P o l}=3.43$ (see Table 1), so $M_{P o l}=3.43-3.5=-0.07$

Source: authors' own study

neutral level (see Table 1), which means that the attitude to German products and services is clearly positive.

Hungary. All dimensions were evaluated slightly above 3. Prestige was evaluated at the lowest level and significantly lower than two other dimensions innovativeness $(L S D: p<0.05)$ and quality $(L S D: p<0.05)$. It was also evaluated at the same level as diversity ( $L S D: p>0.05$ ). All four dimensions were evaluated significantly below the neutral reference point (see Table 1). It can be concluded that Hungarian products and services are negatively associated.

Lithuania. Most respondents evaluated Lithuanian products and services very low. However, diversity was evaluated significantly higher than innovativeness ( $L S D$ : 
Pobrane z czasopisma Annales H - Oeconomia http://oeconomia.annales.umcs.pl

Data: 26/04/2023 16:55:39

DIMENSIONS OF THE COUNTRY OF ORIGIN EFFECT AND THEIR MEASUREMENT

Table 1. Comparing the level of evaluation of products and services to the neutral reference point

\begin{tabular}{|l|l|c|c|c|c|c|}
\hline Country & Dimension & $\mathrm{M}$ & $\mathrm{SD}$ & $\mathrm{SE}$ & Test $t$ & $p$ value $<$ \\
\hline \multirow{5}{*}{ Germany } & Innovativeness & 5.17 & 0.86 & 0.08 & 22.16 & 0.0001 \\
\cline { 2 - 7 } & Diversity & 4.90 & 0.98 & 0.09 & 16.02 & 0.0001 \\
\cline { 2 - 7 } & Quality & 5.25 & 0.84 & 0.07 & 23.75 & 0.0001 \\
\cline { 2 - 7 } & Prestige & 5.27 & 0.92 & 0.08 & 22.00 & 0.0001 \\
\hline \multirow{5}{*}{ Lungary } & Innovativeness & 3.24 & 0.90 & 0.08 & -3.17 & 0.001 \\
\cline { 2 - 7 } & Diversity & 3.20 & 0.93 & 0.08 & -3.74 & 0.001 \\
\cline { 2 - 7 } & Quality & 3.26 & 0.88 & 0.08 & -3.23 & 0.01 \\
\cline { 2 - 7 } & Prestige & 3.08 & 0.97 & 0.09 & -5.04 & 0.001 \\
\hline \multirow{5}{*}{ Poland } & Innovativeness & 2.57 & 0.87 & 0.08 & -12.14 & 0.0001 \\
\cline { 2 - 7 } & Diversity & 2.80 & 0.93 & 0.08 & -8.44 & 0.0001 \\
\cline { 2 - 7 } & Quality & 2.74 & 0.90 & 0.08 & -9.57 & 0.0001 \\
\cline { 2 - 7 } & Prestige & 2.56 & 0.97 & 0.09 & -10.93 & 0.0001 \\
\cline { 2 - 7 } & Innovativeness & 3.43 & 0.94 & 0.08 & -0.80 & $\mathrm{~ns}$ \\
\cline { 2 - 7 } & Diversity & 3.83 & 1.02 & 0.09 & 3.54 & 0.001 \\
\cline { 2 - 7 } & Quality & 3.68 & 1.10 & 0.10 & 1.87 & 0.06 \\
\hline \multirow{5}{*}{ Sweden } & Prestige & 3.48 & 1.19 & 0.10 & -0.18 & $\mathrm{~ns}$ \\
\cline { 2 - 7 } & Innovativeness & 4.70 & 1.10 & 0.10 & 12.27 & 0.0001 \\
\cline { 2 - 7 } & Diversity & 4.31 & 1.14 & 0.10 & 7.75 & 0.0001 \\
\cline { 2 - 7 } & Quality & 4.65 & 1.08 & 0.09 & 11.78 & 0.0001 \\
\cline { 2 - 7 } & Prestige & 4.62 & 1.18 & 0.10 & 10.52 & 0.0001 \\
\hline \multirow{5}{*}{} & & & & & & \\
\hline
\end{tabular}

$\mathrm{N}=129 ; \mathrm{df}=128$; the value 3.5 (the middle of the scale) was taken as a parameter to which a given mean was compared. $\mathrm{M}$ - Mean, $S D$ - standard deviation, $S E$ - standardized error, $t$ test - single sample $t$ test, $n s$ - non-significant.

Source: authors' own study

$p<0.01)$ and also higher than prestige $(L S D: p<0.01)$. Prestige was evaluated at the lowest level and significantly lower than diversity $(L S D: p<0.01)$ and quality $(L S D$ : $p<0.05$ ), but not significantly lower to innovativeness ( $L S D: p>0.05$ ).

All the criteria dropped significantly below the neutral point (see Table 1) which means that Lithuanian products and services are associated negatively to a given extent.

Poland. The given dimensions approached the level close to 3.5 at the scale 1 to 6. Quality of Polish products and services reached significantly higher level comparing to its innovativeness $(L S D: p<0.01)$ and prestige $(L S D: p<0.05)$. Diversity also was evaluated at significantly higher level than innovativeness $(L S D: p<0.05)$ and prestige $(L S D: p<0.0001)$. No differences were observed between quality and diversity ( $L S D: p>0.05)$. These two criteria obtained the level significantly above the neutral reference point, while innovativeness and prestige did not differ from the neutral attitude (see Table 1). Polish products and services, in terms of diversity and quality, are associated positively at the moderate but still significant level.

Sweden. All dimensions reached a level highly above 4. Diversity of Swedish products and services was evaluated lowest and differed significantly from other dimensions: innovativeness ( $L S D: p<0.0001)$, quality ( $L S D: p<0.0001)$, prestige ( $L S D$ : $p<0.0001)$. Compared to the reference point, all the criteria reached significantly above the neutral attitude. This means that Swedish products and services are strongly positively associated. 


\section{Summary}

This research was intended to verify if the $\mathrm{COO}$ effect has a multidimensional character. The previous research (Roth and Romeo, 1992; Bose et al., 2011) suggested a unidimensional character of the country of origin effect. For example, in their research Roth and Romeo did not prove the multidimensional character of the COO in relation to material products. If products or services coming from a particular country were highly evaluated in one dimension, they were perceived similarly in other dimensions. In Roth and Romero's research, all the dimensions were strongly correlated and, on the basis of the factor analysis, researchers created one general factor. It is also important that the above-mentioned authors' objective was to answer the question: which dimension is most often associated with the image of the country. The answer was: all of them to a similar extent; that is, none of them stands out in shaping of a general image of the country of origin. However, the authors did not check if there are any significant internal differences among the evaluations of these dimensions. Thus, the presented research brought up a question whether the tested dimensions of the $\mathrm{COO}$ effect would be internally differentiated in particular countries. Achieving such differentiation could prove the multidimensional character of the $\mathrm{COO}$ effect, without any contradiction to the results obtained by Roth and Romeo.

The conducted research presented the results partially similar to those achieved by Roth and Romeo (1992) and Bose et al. (2011). If products and services from a particular country received positive evaluation, then it referred to all the dimensions. Similarly, if the evaluation of products and services in a particular country was low in one dimension, then they were also perceived negatively in other dimensions. Such results confirm the global character of the evaluation and attitude, and in this way they replicate theses formulated by Roth and Romeo.

However, the presented research indicated some significant differences in the evaluation of the particular dimensions of a given country. This regularity appeared in all the analysed countries. Even considering Germany, which was highly evaluated in terms of all the criteria, there were some statistically significant differences among the particular dimensions (i.e. the diversity criterion was evaluated at the lowest level). In Poland, although the two criteria were evaluated negatively, they did not stand out significantly from the neutral attitude. Polish products and services are positively perceived in terms of their diversity and quality. They are neutrally perceived (neither positively nor negatively) in terms of their innovativeness and prestige. Hungary obtained the results significantly different from zero in terms of all four dimensions, and this means that Hungarian products were evaluated negatively.

The results show that, although the evaluation has a rather global character (positive or negative), the differentiation of the evaluations from particular countries, depending on the criteria, justifies adopting the multidimensional COO model.

Considering the practical issue, the knowledge about how the evaluation of particular dimensions of the $\mathrm{COO}$ is shaped, may prove helpful in development of 
marketing activities in foreign markets, for example, by emphasizing the highest evaluated dimensions in marketing campaigns for offers coming from a particular country. It can be also useful in development of strategic marketing activities to improve the position of dimensions which are evaluated at the lowest levels.

\section{References}

1. Al-Sulaiti K.I., Baker M.J., Country of origin effects: a literature review, Marketing Intelligence and Planning, 1998, Vol. 16, No. 3.

http://dx.doi.org/10.1108/02634509810217309

2. Balabanis G., Diamantopoulos A., Brand Origin Identification by Consumers: A Classification Perspective, Journal of International Marketing, 2008, Vol. 16, No. 1.

http://dx.doi.org/10.1509/jimk.16.1.39

3. Balabanis G., Diamantopoulos A., Gains and Losses from the Misperception of Brand Origin: The Role of Brand Strength and Country-of-Origin Image, Journal of International Marketing, June 2011, Vol. 19, No. 2.

http://dx.doi.org/10.1509/jimk.19.2.95

4. Bikely W.J. and Nes E., Country of Origin Effects on Product Evaluations, Journal of International Business Studies, 1982, Vol. 1, No. 3.

5. Bloemer J, Brijs K., Kasper H., The COOELM Model: A Theoretical Framework for the Cognitive Processes Underlying Country of Origin-Effects, European Journal of Marketing, 2009, Vol. 43, No. 1/2. http://dx.doi.org/10.1108/03090560910923247

6. Bose S., Ponnam A., Country of origin effect on services: an evaluation of entertainment, Managing Leisure, 2011, Vol. 16, No. 2. http://dx.doi.org/10.1080/13606719.2011.559089

7. Hong S.-T., Wyer R.S. Jr., Effects of country-of-origin and product-attribute information on product evaluation: An information processing perspective, Journal of Consumer Research, September 1989, Vol. 16. http://dx.doi.org/10.1086/209206

8. Javalgi R.G., Cutler B.D., Winans W., At your service! Does country of origin research apply to services, Journal of Services Marketing, 2001, Vol. 15, No. 6/7. http://dx.doi.org/10.1108/08876040110407491

9. Johansson J.K., Douglas S.P., Nonaka I., Assessing the Impact of Country-of-Origin on Product Evaluations: A New Methodological Perspective, Journal of Marketing Research, 1985, Vol. 22. http://dx.doi.org/10.2307/3151584

10. Laroche M., Papadopoulos N., Heslop L.A., Mourali M., The influence of country image structure on consumer evaluations of foreign products, International Marketing Review 2005, Vol. 22, No. 1. http://dx.doi.org/10.1108/02651330510581190

11. Leippe M.R., Zimbardo P., Psychologia zmiany postaw i wpływu społecznego, Poznań, Zysk i S-ka, 2004.

12. Liczmańska K., Efekt kraju pochodzenia produktu a decyzje nabywcze konsumentów sektora alkoholi wysoko procentowych, Roczniki Ekonomiczne Kujawsko-Pomorskiej Szkoły Wyższej w Bydgoszczy, 2010, Vol. 3.

13. Melnyk V., Klein K., Völckner F., The Double-Edged Sword of Foreign Brand Names for Companies from Emerging Countries, Journal of Marketing, 2012, Vol. 76. http://dx.doi.org/10.1509/jm.11.0349

14. Meng J.G., Nasco S.A., Clark T., Measuring Country-of-Origin Effects in Caucasians, African-Americans and Chinese Consumers for Products and Services, Journal of International Consumer Marketing, 2007, Vol. 20, No. 2. 
15. Peterson R.A., Jolibert A.J.P., A meta-analysis of country-of-origin effects, Journal of International Business Studies, 1995, Vol. 26, No. 4. http://dx.doi.org/10.1057/palgrave.jibs. 8490824

16. Pharr J.M., Synthesizing Country-of-Origin Research from the Last Decade: Is the Concept Still Salient in an Era of Global Brands?, Journal of Marketing Theory and Practice, 2005, Vol. 13, No. 4.

17. Rezvani S., Dehkordi G.J., Rahman M.S., Fouladivanda F., Habibi M., Eghtebasi S., A Conceptual Study on the Country of Origin Effect on Consumer Purchase Intention, Asian Social Science, 2012, Vol. 8, No. 12. http://dx.doi.org/10.5539/ass.v8n12p205

18. Roth K.P., Diamantopoulos A., Advancing the country image construct, Journal of Business Research, 2009, Vol. 62. http://dx.doi.org/10.1016/j.jbusres.2008.05.014

19. Saran R., Gupta N., Country of Origin Vs. Consumer Perception: A Literature Review, IUP Journal of Marketing Management, 2012, Vol. 11, No. 4.

20. Schooler R.D., Product bias in the Central American Common Market, Journal of Marketing Research, 1965, Vol. 11.

http://dx.doi.org/10.2307/3149486

21. Sikora T., Znaczenie efektu kraju pochodzenia dla komunikacji w biznesie międzynarodowym, Zeszyty Naukowe SGH, 2008, Vol. 23.

22. Wojciszke B., Psychologia Spoteczna, Warszawa, Scholar, 2011.

23. Verlegh P., Steenkamp J., A review of Meta Analysis of Country of Origin Research, Journal of Economic Psychology, 1999, Vol. 20. http://dx.doi.org/10.1016/S0167-4870(99)00023-9

24. Zhou L., Yang Z., Hui M.K., Non-Local or Local Brands? A Multi-Level Investigation into Confidence in Brand Origin Identification and Its Strategic Implications, Journal of the Academy of Marketing Science, 2010, Vol. 38, No. 2.

http://dx.doi.org/10.1007/s11747-009-0153-1

\section{Dimensions of the Country of Origin Effect and their Measurement}

Abstract. The influence of the country's images on consumer attitudes has been defined as the country of origin effect. The aim of the paper was to verify a hypothesis about multi-dimensionality of COO effect. Four dimensions have been introduced: innovativeness, diversity, quality, prestige. The data have been collected with the use of the survey questionnaire. Analysis of variance and t-test have been applied. Although the evaluation is rather globally oriented (positively or negatively), the differentiation of the evaluations from particular countries depending on the criteria confirms multidimensional character of $\mathrm{COO}$ effect. The knowledge about how the evaluation of particular dimensions of the $\mathrm{COO}$ is shaped may prove helpful in development of marketing strategies in foreign markets.

\section{Wymiary efektu kraju pochodzenia i ich pomiar}

Abstrakt. Wpływ wizerunku kraju na postawy konsumenckie definiuje się jako efekt kraju pochodzenia. Celem artykułu była weryfikacja hipotezy o wielowymiarowości efektu COO. Zostały wprowadzone cztery wymiary: nowoczesność, różnorodność, jakość, prestiż. Dane zebrano wykorzystując technikę audytoryjnych badań ankietowych. Jako metodę statystyczną wykorzystano analizę wariancji i test-t. Rezultaty pokazują, że choć ocena jest ukierunkowana globalnie (pozytywnie lub negatywnie), to zróżnicowanie ocen danego kraju w zależności od wyróżnionych kryteriów potwierdza wielowymiarowość efektu COO. Wiedza o tym jak kształtuje się ocena poszczególnych wymiarów efektu kraju pochodzenia może być pomocna w praktycznym kształtowaniu działań marketingowych na rynkach zagranicznych. 